\section{SCIENTIFIC PRODUCTION IN SPORTS SCIENCE JOURNALS: BIBLIOMETRIC ANALYSIS}

\author{
PRODUÇÃO CIENTÍFICA NOS PERIÓDICOS DAS CIÊNCIAS DO ESPORTE: ANÁLISE BIBLIOMÉTRICA \\ PRODUCCIÓN CIENTÍFICA EN LOS PERIÓDICOS DE CIENCIAS DEL DEPORTE: ANÁLISIS BIBLIOMÉTRICO
}

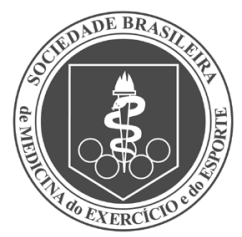

Review Article

ARTIGO de REVISÃo Artículo de REVISIÓN

\begin{abstract}
Danilo Reis Coimbra'
(Physical Education Professional)

Fábio Hech Dominski ${ }^{1}$

(Physical Education Professional)

Clara Knierim Correia'

(Physical Education Professional)

Alexandro Andrade ${ }^{1}$

(Physical Education Professional)

1. Universidade do Estado de Santa Catarina (UDESC), Center for Sport and Health Sciences (CEFID), Department of Physical Education, Sport and Exercise Psychology Laboratory (LAPE), Florianópolis, SC, Brazil.
\end{abstract}

\section{Correspondence:}

Alexandro Andrade. Rua Pascoal Simone, 358, Coqueiros, Florianópolis, Santa Catarina, Brazil. 88080-350.

alexandro.andrade.phd@gmail.com

\begin{abstract}
The aim of this study was to analyze the scientific production of journals on sport and exercise science and physical education in Portuguese that are indexed in the Scopus database by conducting a bibliometric analysis. Six journals related to this field of study and indexed in the Scopus database were selected. Regarding publications, the journals published 3,869 documents while indexed in Scopus, most (90.8\%) of which were original articles. The year with the highest number of publications was $2013(n=473)$. The clusters of keywords that were cited most often ("physical activity" and "exercise") were related to biodynamics. Most journal authors are from Brazil (89.86\%). The Brazilian Journal of Sports Medicine had the highest number of publications $(n=1179)$, the highest average per year $(n=78.6)$, and reached the highest index in the scientific journal ranking (SJR index $=0.331$ ). We concluded that scientific production increased until 2013. The publications with the highest number of citations and the most common study topics are related to the area of biodynamics. Level of evidencell; Review Study.
\end{abstract}

Keywords: Exercise; Bibliometrics; Physical education and training.

\section{RESUMO}

O presente estudo tem como objetivo analisar a produção científica de periódicos das ciências do esporte, do exercício e da Educação Física (CEEEF), na língua portuguesa, indexados no SCOPUS, através da análise bibliométrica. Foram selecionados seis periódicos relacionados às CEEEF e indexados no SCOPUS. Em relação às publicações, no período de indexação no SCOPUS, os periódicos publicaram 3.869 documentos, sendo a maioria (90,8\%), artigos originais. O ano com o maior número de publicações foi $2013(n=473)$. Os clusters de palavras-chaves que mais apareceram estavam relacionados à biodinâmica: "physical activity" e "exercise". Em relação aos autores, a maioria é do Brasil (89,86\%). Em relação aos periódicos, a Revista Brasileira de Medicina do Esporte foi a que mais publicou ( $n=1179)$, com maior média por ano ( $n=78,6)$ e atingiu o maior índice no Scientific Journal Ranking (SJR=0,331). Percebe-se um crescimento na produção até 2013. As publicações com maior número de citações e os temas mais estudados estão relacionadas à área da biodinâmica. Nível de evidência ll; Estudo de Revisão.

Descritores: Exercício; Bibliometria; Educação física e treinamento.

\section{RESUMEN}

El presente estudio tiene como objetivo analizar la producción científica en periódicos de las ciencias del deporte, del ejercicio y de la Educación Física (CEEEF) en idioma portugués, indexados en la base Scopus, a través del análisis bibliométrico. Fueron seleccionados seis periódicos relacionados a las CEEEF indexados en SCOPUS. Con relación a las publicaciones, en el período de indexación en SCOPUS, Ios periódicos publicaron 3.869 documentos, siendo la mayoría (90,8\%) artículos originales. El año con el mayor número de publicaciones fue 2013 (n=473). Los clusters de palabras clave que más aparecieron estaban relacionados a la biodinámica: "physical activity" $y$ "exercise". Con relación a los autores, la mayoría es de Brasil (89,86\%). Con relación a los periódicos, la Revista Brasileña de Medicina del Deporte fue la que más publicó ( $n=1179)$, con mayor promedio por año ( $n=78,6)$ y alcanzó el mayor índice en el Scientific Journal Ranking (SJR =0,331). Se percibe un crecimiento en la producción hasta 2013. Las publicaciones con mayor número de citaciones y los temas más estudiados están relacionados al área de la biodinámica. Nivel de Evidencia ll; Estudio de Revisión.

Descriptores: Ejercicio; Bibliometría; Educación y entrenamiento físico.

\section{INTRODUCTION}

The scientific advancement in the area of sport and exercise science and physical education (SESPE) is mainly a result of public policies that were established to objectively promote the advances in Brazilian science. Among the advances is the establishment of the Brazilian College of Sports Sciences (BCSS) ${ }^{1}$ in 1978. Although the BCSS contributes constantly to graduate programs at stricto sensu level in the initial formation ${ }^{1}$, knowledge production must be expanded to levels of professional intervention and continuing education ${ }^{2}$.

Regarding professional intervention, scientific publications help synthesize and disseminate practical and theoretical knowledge ${ }^{2}$, guiding strategies for the different areas of human movement. Some analyses on 
the production of knowledge in the area of SESPE in Brazil have been published, including study specific subareas such as sports psychology ${ }^{3-5}$ and biomechanics. ${ }^{6}$

In Brazil, the scientific production on SESPE has significantly progressed during the 21st century, with a recurrent phase of funding for research, for example.? Some authors declare that although Brazil is the largest producer of scientific knowledge in South America, the production of knowledge is still considered low when compared with other areas of science?

Despite the large volume of publications ${ }^{8,9}$, some authors ${ }^{1}$ propose some reflections on the scientific production in this area of research in Brazil. They express mainly the need for analysis of the production of knowledge to identify the trends, deficiencies, and effects of this production. Progress of the production of knowledge in general and of SESPE has been observed, and studies that investigate this production are important for the evolution of the field of research ${ }^{10,11}$. In this regard, bibliometrics can be an important method to meet this demand.

Bibliometrics is defined as a quantitative analysis of the bibliographic characteristics of publications in a given field of knowledge, such as chronology, citations, keywords, authors, collaboration networks, institutions, countries, themes, and journals ${ }^{12}$. Bibliometric analyses in the area of SESPE were developed in specific databases such as the Web of Knowledge, Scielo, and Latindex, or in specific journals, 71,14. Databases are considered reliable sources of information for conducting this type of study ${ }^{15}$, as they include periodicals with great scientific relevance.

In this regard, Scopus is considered the largest database of citations and abstracts, and includes more than 21,500 peer-reviewed journals with more than 69 million records. As no evidence has been found with a general approach to scientific production in SESPE in periodicals indexed in Scopus, this study aimed to analyze the scientific production of journals on SESPE in the Portuguese language that were indexed in the Scopus database through a bibliometric analysis.

\section{METHODS}

This is a bibliometric analysis of the journals on SESPE in the Portuguese language that were indexed in the Scopus (Elsevier) database.

\section{Eligibility criteria of journals}

For the purposes of delimitation in this bibliometric analysis, studies published in the journals related to SESPE in the Portuguese language that were indexed in Scopus were selected.

After checking the research area of the journals, the following inclusion criteria were applied: published in Portuguese or have an editorial body and head office in Brazil and available online.

After verification of the eligibility criteria, the following journals were selected: Movimento, Brazilian Journal of Sports Medicine (RBME), Journal of Physical Education, Motriz: Journal of Physical Education, Brazilian Journal of Sport Sciences (RBCE), and Brazilian Journal of Kinanthropometry and Human Performance (RBCDH). The characteristics of the journals are detailed in Table 1.

The key terms "Journal of Physical Education" and "revista da educação física" were used to search for the same journal, which from 2016 came to be called by its English title.

Search strategy of studies

The search was performed on December 11, 2017, in the Scopus database. In the field of research, the names of the journals were used, and the category "Source title" was selected. In the search results, the "Analyze search results" option was selected.

\section{Eligibility criteria of the studies}

The time limit was established by the date of indexing the journal in Scopus, so this varied according to each journal (Table 1).
Table 1. Characteristics of selected journals.

\begin{tabular}{|c|c|c|c|c|c|}
\hline Journal & Webqualis & SJR & Frequency & Institutions & $\begin{array}{c}\text { Period of } \\
\text { Indexing in } \\
\text { SCOPUS }\end{array}$ \\
\hline Movimento & A2 & 0.237 & Quarterly & \begin{tabular}{|c|} 
Escola de Educação \\
Física, Fisioterapia \\
e Dança da \\
Universidade \\
Federal do Rio \\
Grande do Sul/RS
\end{tabular} & $\begin{array}{l}2010 \text { until } \\
2017\end{array}$ \\
\hline $\begin{array}{c}\text { Brazilian Journal of } \\
\text { Sports Medicine } \\
\text { (RBME) }\end{array}$ & A2 & 0.173 & Bimonthly & \begin{tabular}{|c|} 
Sociedade Brasileira \\
de Medicina do \\
Exercício e do \\
Esporte/SP
\end{tabular} & $\begin{array}{l}2003 \text { until } \\
2017\end{array}$ \\
\hline $\begin{array}{c}\text { Journal of Physical } \\
\text { Education }\end{array}$ & B1 & 0.161 & Quarterly & $\begin{array}{c}\text { Escola de } \\
\text { Educação Física } \\
\text { da Universidade } \\
\text { Estadual de } \\
\text { Maringá/PR }\end{array}$ & $\begin{array}{l}2011 \text { until } \\
2017\end{array}$ \\
\hline $\begin{array}{l}\text { Motriz: Journal of } \\
\text { Physical Education }\end{array}$ & B1 & 0.238 & Quarterly & $\begin{array}{c}\text { Universidade } \\
\text { Estadual Paulista/SP }\end{array}$ & $\begin{array}{l}2010 \text { until } \\
2017\end{array}$ \\
\hline $\begin{array}{c}\text { Brazilian Journal } \\
\text { of Spots Science } \\
\text { (RBCE) }\end{array}$ & B1 & 0.187 & Quarterly & $\begin{array}{c}\text { Colégio Brasileiro } \\
\text { de Ciências do } \\
\text { Esporte/PR }\end{array}$ & $\begin{array}{l}2012 \text { until } \\
2017\end{array}$ \\
\hline $\begin{array}{c}\text { Brazilian Journal of } \\
\text { Kinanthropometry } \\
\text { and Human } \\
\text { Performance } \\
\text { (RBCDH) }\end{array}$ & B1 & 0.239 & Bimonthly & \begin{tabular}{|c|} 
Núcleo de \\
Pesquisa em \\
Cineantropometria \\
\& Desempenho \\
Humano da \\
Universidade \\
Federal de Santa \\
Catarina/SC \\
\end{tabular} & $\begin{array}{l}1999 \text { until } \\
2017\end{array}$ \\
\hline
\end{tabular}

\section{Selection of studies and data extraction}

The procedures of the search and selection of studies were performed by two researchers (DC and FD).

For the analysis and discussion of the results the following categories were defined and two researchers (DC and FD) extracted the following data: a) regarding the publication, the type of document, language, funding, year of publication, number of citations and theme (through the extraction of keywords); b) regarding the authors, the countries and collaboration networks; and c) regarding the journals, the number of publications and SCImago Journal and Country Rank (SJR).

The results in relation to the theme and authors were presented using the bibliometric mapping technique. This allows visualizing the characteristics of the scientific production through bibliometric maps. ${ }^{16}$ The program VOSviewer version 1.6.6 (Leiden University, the Netherlands) was used to make the maps. ${ }^{17}$

To analyze the authors and themes on the basis of the keywords, a temporal cutoff of the publications was made, stratifying them into three time points as follows: documents published (1) from 1999 to 2008, (2) from 2009 to 2013, and (3) from 2014 to 2017. For the analysis of the authors with the highest number of publications, those who presented at least five publications were considered. Regarding the keywords, they were considered when cited in at least 10 publications.

\section{RESULTS}

\section{Regarding publications}

During the indexing period in Scopus, the journals published 3,869 documents. Among the types of documents, the journals mostly published original articles $(3512,90.8 \%)$, followed by reviews $(267,6.9 \%)$, editorials $(55$, $1.4 \%)$, errata $(12,0.3 \%)$, letters $(11,0.3 \%)$, and conference papers $(11,0.3 \%)$.

As to language, most publications were available in Portuguese $(n=1672)$, followed by English $(n=846)$ and Spanish $(n=58)$. When available in two languages, most publications were in Portuguese and English $(n=1155)$, English and Spanish $(n=48)$, and Portuguese and Spanish 
$(n=4)$. Only 85 publications were available in all three languages. Only 67 publications mentioned funding, corresponding to $1.7 \%$ of the cases.

The first studies related to sports and exercise sciences in selected journals were published in 1999 by the Brazilian Journal of Kinanthropometry and Human Performance. The year with the highest number of publications (473) by journals was 2013 (Figure 1).

Regarding the citations of the publications, the most cited articles were published by RBME, with emphasis on the years 2013 and 2016, with 628 and 665 citations each year, respectively (Figure 2).

Among the 3,869 publications, the most cited was the article of Perini et al., published in RBME in 2005, which presented 121 citations (Table 2). This study aimed to disseminate the strategy to obtain the technical error of measurement in anthropometry and to evaluate the performance of laboratory trainees. Four of the five most cited studies were in Portuguese and English languages.

Figure 3 illustrates the main themes investigated from the keywords cited by the authors. A larger text font indicates that the keyword was used more often. In the period between 1999 and 2008, 35 different keywords were used at least 10 times. The most used were "physical activity," 'body composition," and "exercise" (54, 50, and 50, respectively). Four different co-occurrence clusters were formed. In the second period, 80 different keywords appeared at least 10 times. The most used were "physical education,"'exercise," and "sport" (137, 84, and 84, respectively). In total, five different clusters of words emerged. In the last period, of 2203 different keywords, 91 were used at least 10 times. The three with the highest occurrence were "physical education," "exercise," and "sport" $(144,132$, and 132, respectively). Six different co-occurrence clusters emerged. It can be observed that the most used keywords in the publications were "physical activity" and "physical education."

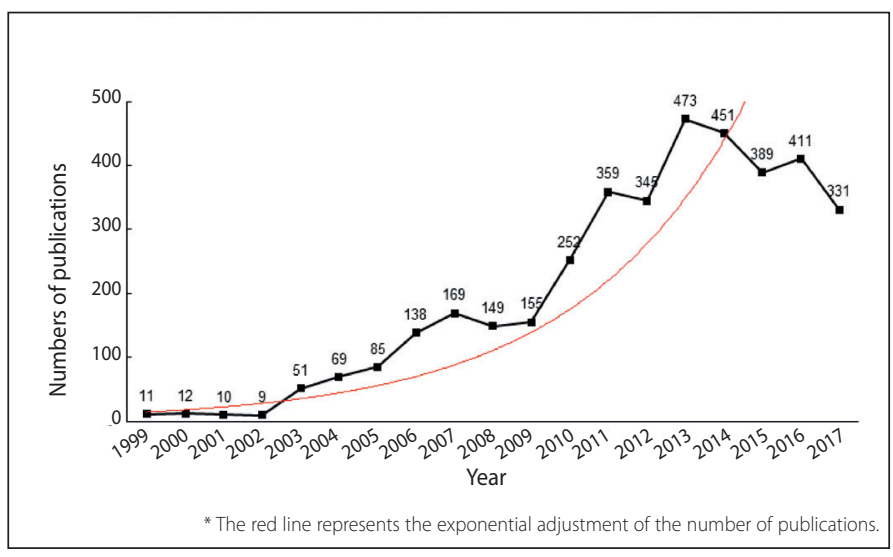

Figure 1. Numbers of publications per year in journals of sports science, exercise and Physical Education of portuguese language indexed in SCOPUS.

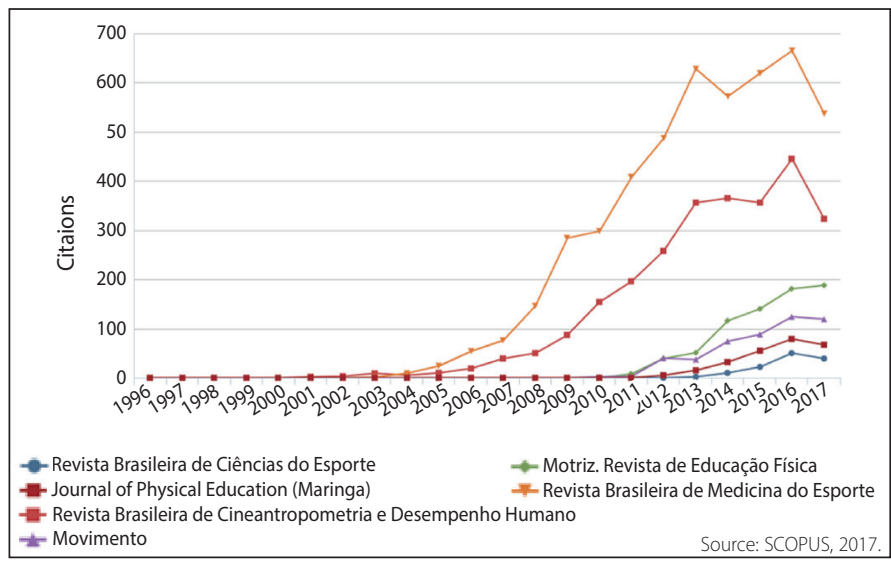

Figure 2. Numbers of citations per year of publications in SESPE journals indexed in SCOPUS.
Table 2. Publications with the highest number of citations year in journals of sports science, exercise and Physical Education of portuguese language indexed in SCOPUS.

\begin{tabular}{c|c|c|c}
\hline Authors/Title & Journal & $\begin{array}{c}\text { Year of } \\
\text { Publication }\end{array}$ & Citations \\
\hline $\begin{array}{c}\text { Perini T.A., de Oliveira G.L., dos Santos } \\
\text { Ornellas J., Palha de Oliveira F. } \\
\text { Technical error of measurement } \\
\text { in anthropometry }\end{array}$ & RBME & 2005 & 121 \\
\hline $\begin{array}{c}\text { Pinto Guedes D., Correa Lopes } \\
\text { C., Pinto Guedes J.E.R. }\end{array}$ & & & \\
$\begin{array}{c}\text { Reproducibility and validity of the International } \\
\text { Physical Activity Questionnaire in adolescents }\end{array}$ & RBME & 2005 & 77 \\
\hline $\begin{array}{c}\text { Florindo A.A., do Rosario Dias } \\
\text { de Oliveira Latorre M. }\end{array}$ & & \\
$\begin{array}{c}\text { Validation and reliability of the Baecke } \\
\text { questionnaire for the evaluation of } \\
\text { habitual physical activity in adult men }\end{array}$ & RBME & 2003 & 71 \\
\hline $\begin{array}{c}\text { Ciolac E.G., Guimarães G.V. } \\
\text { Physical exercise and metabolic syndrome }\end{array}$ & RBME & 2004 & 60 \\
\hline $\begin{array}{c}\text { Schneider C.D., de Oliveira A.R. } \\
\text { Oxygen free radicals and exercise: } \\
\begin{array}{c}\text { Mechanisms of synthesis and } \\
\text { adaptation to the physical training }\end{array}\end{array}$ & RBME & 2004 & 44 \\
\hline
\end{tabular}

\section{Regarding authors}

We found publications by authors from institutions in 48 countries. Institutions in Brazil were the ones that presented the most publications, followed by those in Portugal and Spain. Table 3 shows the top 10 countries in relation to the number of publications in sports and exercise journals indexed in Scopus.

Regarding authors and their collaboration networks (Figure 4), an evolution was observed. In the first period, 73 authors were in at least five publications from eight different collaboration networks. We highlight the leadership of the researchers Edilson Serpeloni Cyrino (25 publications) and Fábio Yuzo Nakamura (23 publications). In the period from 2009 to 2013, progress was observed for 180 different authors who published at least five studies. The second period had 15 different employee networks. The researcher with the highest number of publications remained to be Edilson Serpeloni Cyrino (20 publications), followed by Edio Luiz Petroski (19 publications). In the last analyzed period (from 2014 to 2017), 144 different researchers had at least five publications, forming nine networks of collaborators. The authors with the highest number of publications in this period were Alexandre Fernandes Vaz (24 publications) and Jailson José Bassani (16 publications).

\section{Regarding journals}

RBME was the journal with the highest number of publications, with 1,179 documents, and the journal with the highest average number of publications per year in its indexing period (from 2003 to 2017) in Scopus, with an average of 78 publications, six publications per year. The $R B C D H$ presented 932 publications, followed by Movimento $(n=583)$, Motriz $(n=$ $500)$, Journal of Physical Education $(n=351)$, and RBCE $(n=324$; Figure 5).

RBME had the highest SJR index in the period analyzed, reaching a value of 0.331 in 2009. Currently, $R B C D H$ has this highest metric in relation to the other journals, presenting a SJR index of 0.239 in 2016. This journal was also the first to present this metric, in the year 2000 (Figure 6).

\section{DISCUSSION}

This study aimed to analyze the scientific production of journals of SESPE in the Portuguese language that were indexed in Scopus by conducting a bibliometric analysis. The bibliometric data analyzed were related to publications, authors, and journals. 


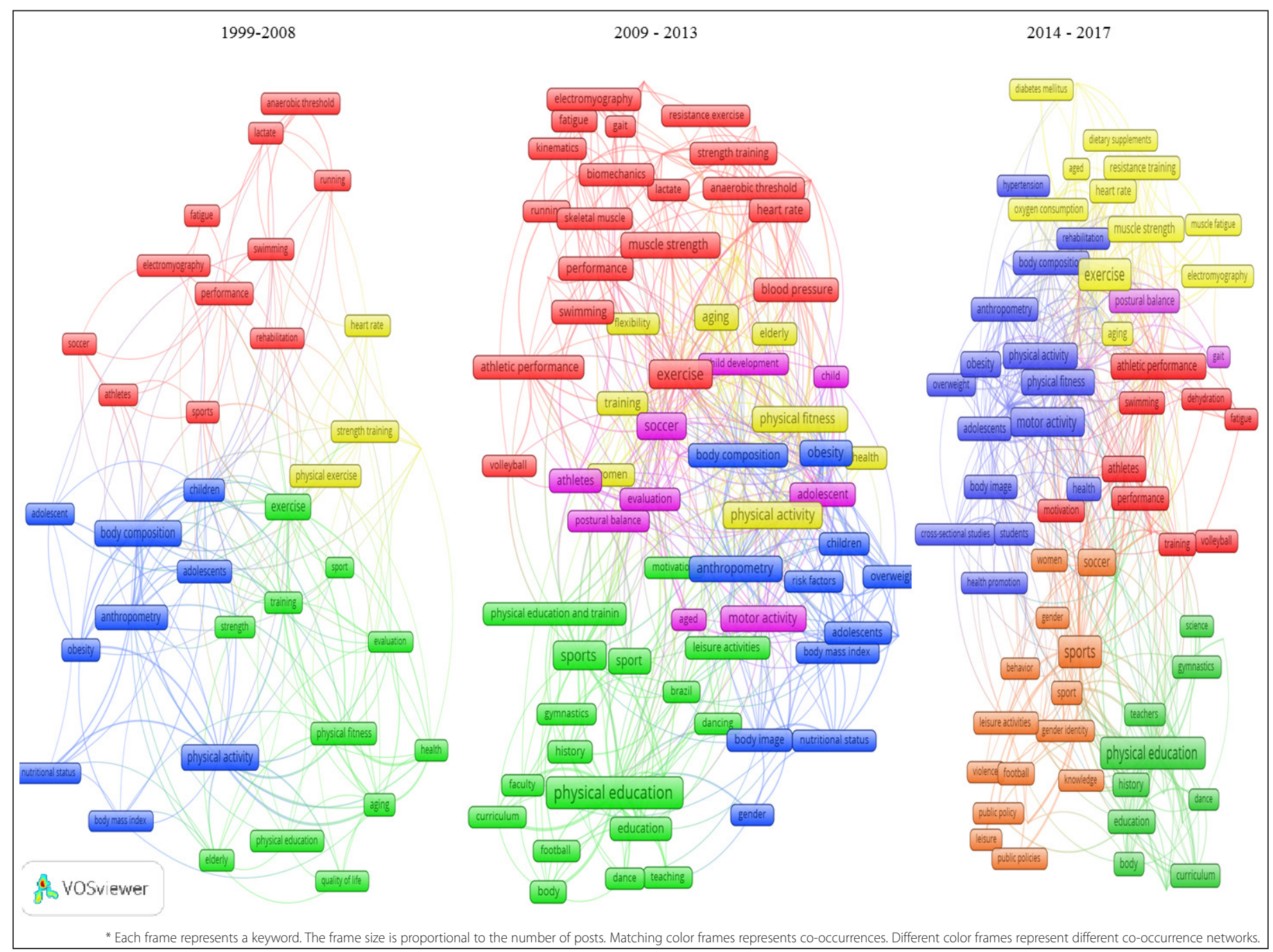

Figure 3. Keywords used by authors.

Table 3. Number of publications by country ( $n / \%)$.

\begin{tabular}{c|c|c|c}
\hline & Country & $\begin{array}{c}\text { Number of } \\
\text { publications (n) }\end{array}$ & Percentage (\%) \\
\hline 1 & Brazil & 3477 & 89.86 \\
\hline 2 & Portugal & 228 & 5.89 \\
\hline 3 & Spain & 158 & 4.08 \\
\hline 4 & Undefined & 79 & 2.04 \\
\hline 5 & United States & 71 & 1.83 \\
\hline 6 & Canada & 28 & 0.72 \\
\hline 7 & United Kingdom & 25 & 0.64 \\
\hline 8 & Chile & 21 & 0.54 \\
\hline 9 & Argentina & 20 & 0.51 \\
\hline 10 & Italy & 15 & 0.38 \\
\hline
\end{tabular}

\section{Publications}

The scientific production on SESPE had a significant advancement in the beginning of the XXI century, with the highest number of publications in the year 2013. The increase in the number of graduate programs and researchers with PhD in the Brazilian universities, and investments focused on academic research are factors that contribute to the increase in the scientific production in this research area ${ }^{18}$. However, such increase must also be accompanied by quality. One way to evaluate is by the number of citations that a study receives after publication ${ }^{19}$. In the analysis, the journal that presented the highest number of citations was RBME, as it had the highest number of publications per year and has been indexed in the Scopus database since 2003.

In the analysis of the studies that presented the number of citations, a predominance of research studies from the biodynamic area was observed.
The theme analysis, conducted with the keywords used by the authors, revealed that the production of knowledge in SESPE indexed in Scopus was strongly associated with the biodynamic study area, in a reduced way in the sociocultural area, as reported by some authors ${ }^{8,20}$. However, some research groups ${ }^{21}$ verified that the subarea with the highest number of publications in 2014 was pedagogical sociocultural research. However, the study analyzed a total of 12 journals, including those with B2 extract of Qualis.

The investigation of the sports sciences showed predominance over some modalities such as football, swimming, and running, which were present in the three periods of publications analyzed through the keywords. Subsequently, volleyball, dance, and gymnastics were also included in the scenario of scientific production. We can infer that research on such sports reflects the tradition and popularity of these practices in the country with the most published Portuguese-language SESPE journals indexed in Scopus, which is Brazil.

\section{Authors}

As in other areas, Brazil has been the most productive country in South America in relation to sports sciences, corroborating with findings in the literature that investigated research in the area between 1970 and $2012^{7}$. This result is mainly due to the increase in the number of research studies conducted by authors with PhDs in the country, ${ }^{18}$ which is due to the increase in the number of postgraduate programs in the area and greater investment by research funding agencies ${ }^{22}$. The production of knowledge in sports sciences is predominantly from public institutions, a fact that can be attributed to government policies that are aimed at 
farinatti, p.d.t.v.

de tarso veras farinatti, $p$.
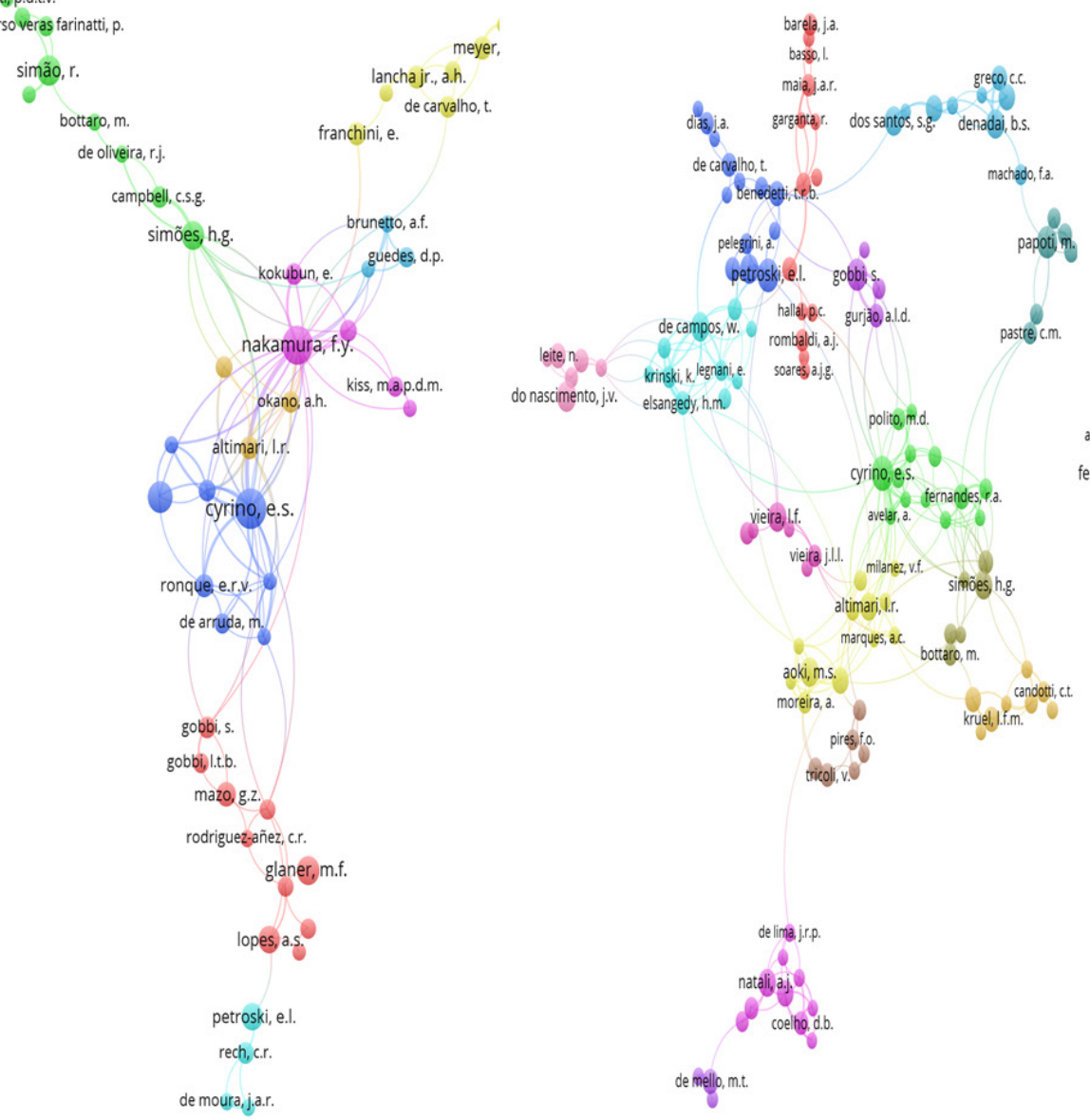

galatit th

simão,

bottaro, $m$

lancha jr., a.h.

de carvalho,

8.2

campbell, c.s.g.

ob

ado, ti.

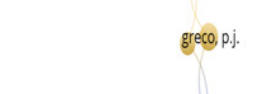

greco, p.j.

chagas m.h.

coeline d.b.

garcales.

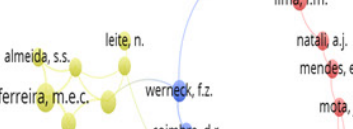

coimbra, d.r.

ugrinowitsch, $h$. rossjif.e.

fernandes, r.

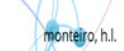

codogno, j.s.

christofaro, d.g.d.

do nascimentoj.j.

ramos, $v$.
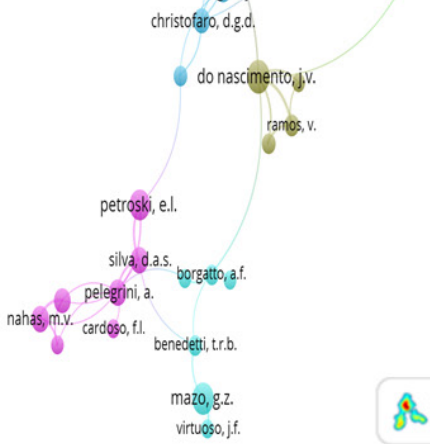

de mello, m.t.

virtuoso, j. j.

\& vosviewer

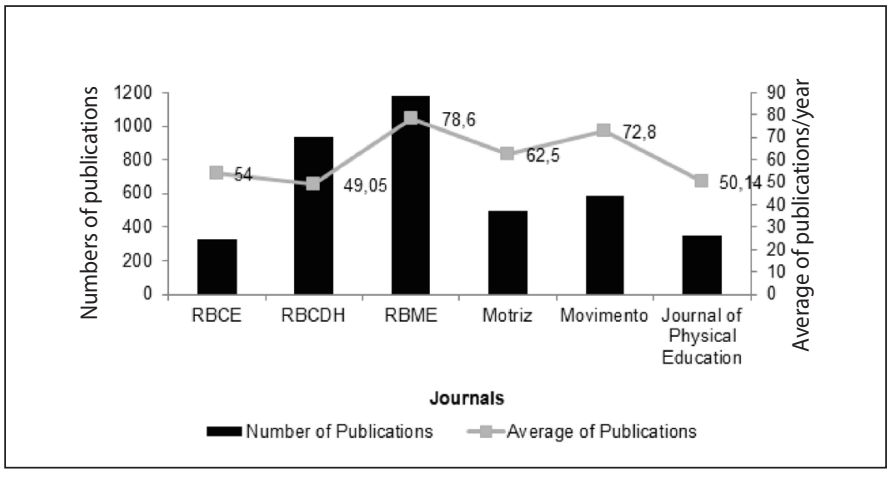

Figure 5. Number and average of Publications per journal in the period of indexation.

stimulating scientific production in the public sector ${ }^{7}$. Analysis in relation to institutions was not conducted in the present study, which is a limitation of this study.

On the other hand, some studies ${ }^{7}$ suggest that despite the high-quantity production, researchers in Brazil have published articles with low impact ${ }^{22}$ because they have not been cited at all.

This result may be due to the current process in which researchers tend to take into account predominantly the impact factor of journals

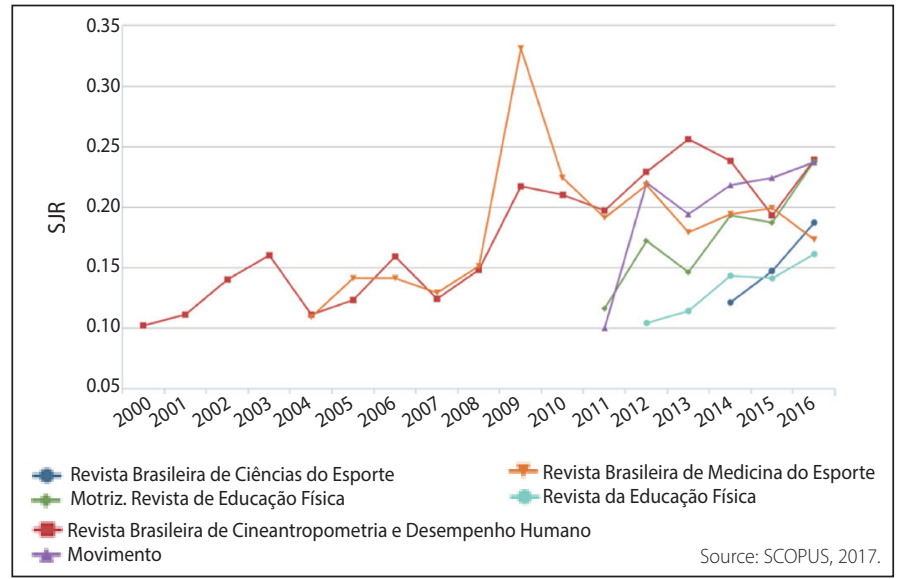

Figure 6. SJR of SESPE journals indexed in SCOPUS.

rather than the specificity of the journal area, resulting in publications in related or even unrelated areas $^{8}$. Moreover, the predominance of publications by authors related to institutions in Brazil indicates that SESPE journals indexed in Scopus are not targeted by researchers from other countries to publish their research. 


\section{Journals}

The analyzed journals have contributed significantly to the state of the art in the field of SESPE through the dissemination of knowledge through qualified and relevant research.

The last journal to be indexed in Scopus was the RBCE, in 2012. According to one study ${ }^{8}$, in the scientific community, there is an understanding that international insertion is an indicator of quality. In addition, all indexed journals were published in the English language, which provides greater visibility to publications.

The SJR index was introduced in 2008 and is available in open access ${ }^{23}$. An upward trend was observed in relation to this metric in four of the six journals analyzed since their indexing in Scopus. SJR grades journals according to the number of citations received within 3 years of publication, differently from the Journal of Citation Reports (Thomson Reuters).

Despite the increase in publications up to 2013, the number has since decreased. We infer that this may be due to the interest of the researchers in publishing their works outside the scenario of national journals, opting for the submission of papers to international journals with the highest impact factors. In addition, the authors who were featured in the first two periods analyzed did not appear in the period from 2014 to 2017, and fewer researchers published at least five studies in the latter period than in the period from 2009 to 2013. Such results may be a consequence of this process, but these data were not verified in the present study.

This study presents the limitation of having included only journals on SESPE in the Portuguese language. The knowledge production in the area can also be linked in journals of other related areas such as medicine, psychology, and education.

\section{CONCLUSION}

The analysis of the scientific production of periodicals on SESPE in the Portuguese language that were indexed in Scopus allowed us to conclude that production increased until 2013, when the number of publications started to decline. The publications with the largest number of citations and the most studied themes are related to the area of biodynamics. The predominance of researches by authors of Brazilian institutions shows that Portuguese-language SESPE journals indexed in Scopus are not yet targeted by research groups from other countries. The authors' analysis revealed clearly defined groups of collaboration networks. The Brazilian Journal of Sports Medicine has a greater number of publications in the period of indexation in Scopus, besides the highest average per year and the most cited studies.

\section{FUNDING}

This study was supported by the FAPESC (Research and Innovation Support Foundation of the State of Santa Catarina) for financial support through research (Project n. 2287/ PAP 04/2014). This study was financed in part by the Coordenação de Aperfeiçoamento de Pessoal de Nível Superior - Brasil (CAPES) - Finance Code 001.

All authors declare no potential conflict of interest related to this article

AUTHORS' CONTRIBUTIONS: Each author made significant individual contributions to this manuscript. DRC (0000-0002-6055-0667)*: Conceived the work, worked on the writing and revision of the work and approval of the final version of the manuscript. FHD (0000-0003-1767-6405)*: Carried out the data acquisition, analysis and interpretation, writing of the work and approval of the final version of the manuscript. CKC (0000-0002-9510-2266)*: Worked on the writing and revision of the work and approval of the final version of the manuscript. AA (0000-0002-6640-9314)*: Performed the critical review of the intellectual content of the work and approved the final version of the manuscript. *ORCID (Open Researcher and Contributor ID).

\section{REFERENCES}

1. Neto VM, Gunther MCC, Bossle F, Wittizorecki ES, Molina RMK. Reflexões sobre a produção do conhecimento em educação física e ciências do esporte. Rev Bras Cienc Esporte. 2006;28(1):145-65.

2. Nunes HFP, Bettanim MR, Chelles C, Nunes REP, Drigo AJ. Treinamento desportivo: perfil acadêmico dos líderes de grupos de estudo brasileiros. Rev Bras Ciências Esporte. 2017;39(4):338-46.

3. Dominski FH, Vilarino GT, Coimbra DR, Silva RB, Casagrande P de O, Andrade A, et al. Análise da produção científica relacionada à psicologia do esporte em periódicos das ciências do esporte de língua portuguesa. J Phys Educ. 2018;29(1):1-14.

4. Andrade A, Brandt R, Dominski FH, Vilarino GT, Coimbra D, Moreira M. Psicologia do Esporte no Brasil: Revisão em Periódicos da Psicologia. Psicol em Estud. 2015;20(2):309-17.

5. Gomez S, Coimbra R, García G, Filho B, Gomez SS, Coimbra DR, et al. Análise da produção científica em psicologia do esporte no brasil e no exterior. Rev Iberoam Psicol del Ejercício y el Deport. 2007;2(1):25-40.

6. Candotti CT, Loss JF. Aprodução científica brasileira na área de biomecânica. Rev Bras Ciências Esporte. 2006;28(1):121-9

7. Andrade DC, Lopez BA, Ramirez-Campillo R, Beltran AR, Rodriguez RP. Bibliometric analysis of South American research in sports science from 1970 to 2012. Motriz: Rev Educ Fis. 2013;19(4):783-91.

8. Tani G. Editoração de periódicos em Educação Física/Ciências do Esporte: dificuldades e desafios. Rev Bras Ciências Esporte. 2014;36(4):715-22.

9. Coutinho RX. Análise da produção de conhecimento da Educação Física brasileira sobre o cotidiano escolar. Rev Bras Pós-graduação. 2012;9(17):491-516.

10. Virtuoso JF, Haupenthal A, Pereira ND, Martins CP, Knabben RJ, Andrade A. A produção de conhecimento em fisioterapia: análise de periódicos nacionais (1996 a 2009). Fisioter em Mov. 2011;24(1):173-80

11. Rosa S, Leta J. Tendências atuais da pesquisa brasileira em Educação Física Parte 1 : uma análise a partir de periódicos nacionais. Rev bras Educ Fís Esporte. 2010;24(1980):121-34.

12. Bellis $\mathrm{N}$ de. Bibliometrics and citation analysis: from the science citation index to cybermetrics. $1^{\text {th }}$ ed. EUA: Scarecrow Press; 2009
13. Perez-Gutierrez M, Lagos-Hernandez RI, Izquierdo-Macon E. Sport Sciences' Scientific Production Published in Chile (1912-2014): a Bibliometric Approach. Movimento. 2016;22(4):1121-35.

14. Xianliang L, Hongying Y. A Bibliometric Analysis on China Sport Science(2001-2010)Based on CSSCI Literature. Phys Procedia. 2012;33(2):2045-54.

15. Prieto J, Sampaio J, Gómez M-A. Revisão bibliométrica da produção científica no handebol. Cuad Psicol del Deport. 2015;15(3):145-54.

16. Vošner $\mathrm{HB}$, Kokol $\mathrm{P}$, Bobek $\mathrm{S}$, Železnik $\mathrm{D}$, Završnik J. A bibliometric retrospective of the Journal Computers in Human Behavior (1991-2015). Comput Human Behav. 2016;65(2016):46-58.

17.Eck NJ Van, Waltman L. VOSviewer Manual [Internet]. 1 January 2013. 2013. 1-28 p. Acesso em: 17 mai 2018. Available from: http://www.vosviewer.com/documentation/ Manual_VOSviewer_1.5.4.pdf

18. Helene AF, Ribeiro PL. Brazilian scientific production, financial support, established investigators and doctoral graduates. Scientometrics. 2011;89(2):677-86.

19. Manoel EJ, Carvalho YM De. Graduate studies in Brazilian physical education: the (fa-tal) attraction to biodynamics. Educ Pesqui. 2011;37(2):389-405.

20.Castro ZC De, Henrique P, Silva C, Silva I, Lüdorf A, Maria S, et al. A produção científica em educação física de 2001 a 2010: caminhos da construção de um campo. Movimento. 2017;23(3):869-82.

21. Decian MR, Caputo EL, Stein F, Cardozo PL, Lessa HT, Cardoso RK, et al. A produção do conhecimento em Educação Física e suas subáreas: um panorama a partir de periódicos nacionais da área. Rev Bras Atividade Fis Saúde. 2017;22(3):261.

22. Kokubun E. Pós-graduação em educação física no Brasil: indicadores objetivos dos desafios e das perspectivas. Rev Bras Ciências do Esporte. 2003;24(2):9-26.

23. Nassi-Calò L. Evaluation metrics in science: current status and prospects. Rev Lat Am Enfermagem. 2017;25:1-3. 